\title{
Approaches Using Social Media Platforms for Teaching English Literature Online
}

\author{
Azadeh Mehrpouyan 1 \\ Assistant Professor, Department of English Literature, \\ Velayat University, Iranshahr, Iran \\ Elahesadat Zakeri \\ The University of British Columbia, Faculty of Arts, \\ Department of English, Vancouver, Canada
}

\section{Abstract}

In the modern era of globalization, language and literature learning and comparative literary competencies are inextricably intertwined. Online learning and teaching, and telecollaboration are a great benefit to literature students who do not have face-to-face intercultural opportunities with members of diverse languages, literature, and cultures. Even, online teaching and learning make academics borderless and remove walls. The present study explores principles and new strategies for teaching English literature online. This article addresses how to adopt literary lesson plans for different types of learners, set clear expectations with students, and build rapport and community with students in teaching literature online. This research discusses the right EdTech tools and curricula support and investigates the way to use social media platforms e.g. YouTube as supplementary sources in e-teaching and e-learning for literary content. The results show that online pedagogies can develop Literature educators and students' skills and promote their literary knowledge along with converting a Web-primarily based totally environment into a social network with social media platforms crossing teach, learn and lands, inaccessible areas, and those who have limited instructive supports and facilities for creating equal opportunities.

Keywords: online teaching, teaching strategies, social media platform, teaching English literature

\section{Introduction}

Practical trends for e-learning development in higher education are important to universities (Asgari, \& Mehrpouyan, 2016). Online classes have come to be a distinctly

\footnotetext{
${ }^{1}$ Corresponding Author
} 
popular method for college students to develop their education practically. Teaching an online direction requires special techniques from the face-to-face classroom hence instructors must undertake or increase their competencies to the online learning environment, to make their materials effective and engaging for students. Special teaching strategies can enforce to improve instructors' online education and make the online class a successful experience for each professor and their learners. Online teaching also needs exclusive kinds of interactions with students. Effective online teaching depends on gaining knowledge of experiences, which are appropriately facilitated and designed by methods of knowledgeable instructors. Since inexperienced students of English literature in e-classes have distinct studying patterns and a mixture of methods, online instructors ought to plan activities that consist of multiple styles of learning for different subjects e.g. poetry, fiction, drama, etc. Teaching methods have to also be tailored to the new learning environments. This paper covers the following forms of literature for an online class with below concepts and objectives: prose, poetry, story, play Biography, and autobiography, and essay.

Prose: Teaching prose seeks to develop knowledge, comprehension in the students. They are enabled to evaluate and criticized the thought and factual content. They are taught various forms of the literature available. Acquiring the ability to understand its meaning and theme they become able to criticize and review it on both factual as well as psychological plans.

Poetry: Teaching poetry under literature seeks to develop understanding and appreciation in the students about the various aspects of poetry so that they can understand and appreciate its theme. They are also expected to memorize the poem while being to analyze and criticize various forms of poetry.

Story and play: Teaching story and play seek to provide knowledge and understanding so that the students can analyze and criticize its different characteristics and aspects. They also become able to know where we have facts, events, and other occurrences as mentioned in the story.

Biography and autobiography: concerned with the effective aspect emphasizing acquiring knowledge and understanding about the lifestyle of the person, main incidents, and events these make one able to criticize and analyze the role in the specific field.

Essay: Teaching essays under literature seeks to develop knowledge and understanding in the students so that they develop skills of writing and evaluation on a subject while appreciating different forms of essays.

To undertake literary curriculum for various mentioned forms of literature and different level of learners should set clear expectations with students, and construct rapport and community with students in instructing literature online strategies for educating English literature online. In this article, the method to use social media 
platforms such as YouTube as supporting sources in e-teaching and e-learning is focused on literary content in different genres.

The usual face-to-face learning space is instructor-centered. The educator controls the transfer of the information and lessons. With the fast development of the Internet, "access to widespread e-sources and materials: original literary texts, critical reviews, reading aloud the literary texts, live drama performance, etc., students are no longer dependent on college for gaining knowledge". The potential to learn online has altered this dynamic enabling cyberspace that is monitored and discussed. A studentcentered online session that can increase interactivity and collaboration. Online instructors are now facilitators of data guiding college students towards solutions. Some change/amendment /improvement/update to the instructor's pedagogy is required. For online education to be successful, educators, as properly as s, should target students to take on new roles in the teaching-learning relationship, and colleges have to be inclined to launch manage of gaining knowledge of to the college students (Instructional Strategies for Online Courses, 2011). Online instructors have discovered that by using incorporating a "full range of interactive methodologies" (Instructional Strategies for Online Courses, 2011), online discussions and forums produce higher quality, deeper communication, and responses. Below are countless teaching strategies identified with the aid of the universities" online Network for improving the strategies used in the face-to-face class that can be transferred into an online education environment in different scopes of instructional strategies for online literature courses: forum/discussion, assignments, assessments, projects, online presentation, collaborative learning, lecture, case study, etc. However, social media platforms for teaching English literature online are crucial and helpful. The question of this study is what approaches to use these platforms for teaching English literature online with a special focus on YouTube.

The research method was used is the library and literature review method and practical and experimental methods were employed to conduct this study.

\section{Literature review}

Online educational methods talk over the ways and approaches that guide the organization of learning activities, course content, and student engagement in online courses (Bonk and Dennen 2003). Posting self-introduction videos at the start of a web category so participants could feel that they understand their peers higher is an example of an educational strategy. Strategies often adopted in online courses embrace (1) promoting interactivity through asynchronous and synchronous communication or delivery (Ku et al. 2011; Lawton et al. 2012); (2) facilitating the appliance of ideas (Steinberg 2010; Strang 2012); (3) mistreatment video demonstrations, like screencasts for demonstrating tools and programs (Gemmell et al. 2011); and (4) transfer a robust social presence or a way of belonging to a learning community (Thomas et al. 2008; Zhang and Walls 2006). 
Students in online quantitative courses like statistics have restricted access to faceto-face support and have a better rate of attrition than that of face-to-face courses (Ariadurai and Manohanthan 2008). The shortage of acceptable and deep interaction may be a common issue in online courses because students and instructors area units set in several geologic locations (Moore 1991). This lack of interaction will simply lead to a way of isolation and frustration and a high dropout rate in online courses (Willging and Johnson 2004).

Interaction permits students in online categories to move and cooperative learners. There are unit three sorts of interaction in online courses: student-to-instructor, student-to-content, and student-to-student interaction (Moore 1989). student-toinstructor interaction refers to dialog between students and the teacher, moreover because of the engagement of the scholars and teacher within the learning and teaching method (York et al. 2007). Student-to-content interaction refers to the quantity of substantive interaction occurring between the learner(s) and the content (e.g., texts, audios, and videos). Student-to-student interaction refers to the dialog and exchanges between and/or among very different participants in a web course. These interactions affect not solely however students understand their learning conjointly the\} overall instructional expertise however also the perceived quality of the instruction and learning in a web course (Bonk and Cunningham 1998). Encouraging students to retort to every different and also the teacher in ways in which demonstrates essential thinking and application after all ideas may also promote higher-level psychological feature skills (Davis and Snyder 2012; Lawton et al. 2012). Students who interact in cooperative learning will higher relate new Cunningham to the knowledge they already possess and mirror on their viewpoint and people of others to reach a comprehensive understanding of a difficulty (Miller and Redman 2010).

Students could move with each other and their teacher through synchronous or asynchronous communication. Synchronous communication depends on mounted conferences in time and permits issues to be right away addressed throughout the educational method (Ku et al. 2011). For instance, mistreatment Elluminate, an online conferencing program, to deliver a statistics category (i.e., mistreatment synchronous communication) was found to be more practical than having a text-based asynchronous communication delivery mode (Myers and Schiltz 2012). Asynchronous communication offers a lot of flexibility for college kids preferring to figure severally and provides longer for college kids to mirror on their learning. In asynchronous communication, students work at their own pace and generally move with one another through rib discussion boards (Ku et al. 2011). Asynchronous communication conjointly permits students to mirror on readings and what they are learning from others, elaborate on comments, and post stimulating inquiries to encourage others to suppose more a few topics. This leads students to more develop their ideas or take into account new ways in which of thinking (Majeski and fodder 2007). However, students might not be happy with their instructors delayed 
explanations to their queries, and will not feel that the teacher is approachable, and/or feel comfortable in collaborating with their peers with asynchronous communication (Summers et al. 2005). Strang (2012) noted that mathematicaloriented topics area unit tougher to find out and teach, and it should be ideal to possess each synchronous and asynchronous communication to facilitate active applications and interaction to enhance learning. However, because several online students ask for online courses to avoid mounted meeting times, it is sensible to adopt asynchronous communication for online courses (Huan et al. 2011).

\section{Methods}

Data were collected from practical instructional strategies and experiences from the actual online literature classes and students' reflections to a different range of strategies and course design to help students to learn literature in an online setting. The study was conducted through literature review and mainly empirical and descriptive-analysis methods practically to cover the objectives of the study the right EdTech tools and curricula support and investigates the way to use social media platforms e.g. YouTube as supplementary sources in e-teaching and e-learning for literary content.

\section{Results and discussion}

\section{1. Prime Social Media Platform for Teaching English Literature Online}

This article has a special focus on YouTube as a social media platform to help to undertake literature subjects. Some literary subjects are difficult to understand and this platform might be helpful. The re-enactments of Shakespeare's drama exist in YouTube movies and short videos contain them in the literature classes. Instead of college students simply analyzing a textual content version of Othello, why no longer have them also watch a live performance of Othello to get them significantly inspired to study literature? These one-of-a-kind types of movies can be used to complement the online literature classes. Students' comments have been improved as they like listening to the author's talk on why they wrote their literary works etc. The students are now interested in literature by enjoying multimedia. Some approaches to use this social media platform are suggested to literature instructors for their classes in a variety of literary genres. Prime Social Media Platform for e-Teaching English Literature can be included: Live Performances of Plays, Reading Poems, Writer Interviews and Biographies, Evaluation of Literary Works, Students' Performances and Experiences, Performed literary pieces, Musical Selections of Many Historical Literary Periods, Full-Length Movies in 10-Minutes, Radio Productions and Audiobook Readings (Figure.1) 
Figure1. Social Media Platform for e-Teaching English Literature

\section{Social Media Platform for eTeaching English Literature}

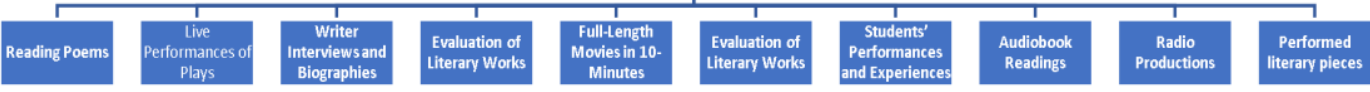

\subsection{Watch Live Performances of Plays}

YouTube has play performances particularly Shakespeare performances e.g. Othello, Hamlet, and The Merchant of Venice as properly as other Shakespeare plays. Students can watch specific remakes of these performances, examine, and contrast which overall performance they like best. Students can additionally stage their renditions of a dramatist and put up their videos. YouTube has many renditions of Hamlet from during the 20th century. It is fascinating to see how various actors interpret the same lines "To be or now not to be." Each actor has his way to specify these lines and it is enjoyable for college students to compare/contrast these performances in an online argument forum (Animated Tales of Hamlet).

\subsection{Retain Reading Poems Aloud By the Poets}

In a video, Langston Hughes reads a piece of his literary work "The Negro Speaks of Rivers." Being attentive to the poet's voice helps Literature students perceive his motivations and aspirations for writing that literary work. Whereas Hughes reads his literary work, one might hear in his voice the pain that racial discrimination points to. Hearing this ache enables college students to apprehend an extra non-public dimension of the poem. In the discussion forum, the online teacher can then ask college students what their concept about the poet is and how to investigate the reviews and modify their perception of the poem (Negro Speaks of Rivers).

\subsection{Listen to Rare Writer Interviews and Biographies}

In an uncommon interview, John Steinbeck talks about why he wrote the Grapes of Wrath. YouTube movies allow college students to hear and see the creator and better apprehend the motivations behind their literary works. It is gratifying to arouse students' consciousness by asking questions about what they completed regarding these authors from these movies and students might then observe however being attentive to these interviews changed their interpretations of the literary piece (Steinbeck video).

\subsection{Review the Evaluation of Well-Known Literary Works}

YouTube has a literary evaluation of many notable works such as Robert Frost's Mending Wall. The instructor can ask students if they agree or disagree with the 
literary analysis, and why. (Literary Analysis of the Mending Wall by way of Robert Frost).

\subsection{Observe Other Students' Performances and Experiences of Literary Pieces}

Students can examine how different college students have re-enacted a play they are analyzing in class. Students are influenced to then recreate their re-enactments of this play for a full understanding of the play. It is enjoyable for college students to embed these scholarly films in their dialogue boards and to talk about what they like or dislike about the performance.

\subsection{Involve in performed literary pieces in their native tongue}

When teaching Dante's Inferno, there is a YouTube video of Dante's Inferno in its authentic language, Italian. Listening in Italian helps the college students get a concept of how the poem sounds in its native language (La Divina Commedia).

\subsection{Give Ear to Musical Selections of Many Historical Literary Periods}

If, for example, the professor instructing the Harlem Renaissance, one will locate many videos presenting the track of the Harlem Renaissance. When students pay attention to the music, they can attempt to think about sitting in a jazz club listening to a band of that period (Harlem Renaissance).

\subsection{Receive Full-Length Movies in 10-Minute Intervals of the Preferred Literary Pieces}

Possibly literature students begin reading Hamlet according to their syllabus, might watch a full-length movie of Hamlet in ten-minute intervals on YouTube, or might watch short clips or selected videos. The professors can have students compare/contrast the movie adaptation with the original text.

\subsection{Enjoy Radio Productions of Great American/ British Plays}

Students can examine a play like the Glass Menagerie and then listen to the radio productions and compare/contrast with what they have read. Listening to these old radio productions additionally helps college students understand how older generations entertained themselves before the invention of the television (World Performance of Glass Menagerie).

\subsection{Have Audiobook Readings of a Literary Novel/Poem/Drama}

YouTube has chapter-by-chapter readings of preferred novels such as The Grapes of Wrath. Students can pay attention to the complete novel in ten-minute intervals. Listening to a novel offers any other dimension of enjoyment and understanding for the student (Meet Ray Bradbury). Hence, the literature professors might implement their e-creative and e-innovative techniques in teaching methods online by the manner of the usage of multimedia platforms, communications, apps, browsers, websites, cyber play, and games, bulletins, chatrooms, blogs, wikis, linguistic 
communication process, podcast, direction administration systems, annotated digital editions, text-analysis tools, ASCII text file applications, and YouTube channel (Lancashire, 2009).

There is a persevering dialogue in the educational literature that the use of such social media and social networking sites would facilitate collaborative learning. It is human psychology usually that such communication media science appears solely for entertainment, but it is mentioned right here cautiously that if such communication technology would be observed with due interest prove productive. It is essential to acknowledge that most university students presently adopting social media conversation to engage with colleagues, instructors and additionally making the crew be in contact with old pals and even a convenient supply of transferring the resources. In the current era, the majority of college students having different social media community agencies like WhatsApp, Facebook pages following special tutorial web pages to upgrade their knowledge.

Accordingly, the use of online social media for collaborative learning, interplay with mentors and colleagues Leadbetter student engagement, which hence influences student's academic performance. The greater training authority ought to provide such a platform that can nurture the student's mental talents. Based on the empirical investigation, it would be stated that students' engagement, social media conversation gadgets facilitate college students to retrieve data and interact with others in real-time related to sharing educating substances contents. Additionally, such sophisticated conversation gadgets would prove to be more beneficial to the students who feel too shy in front of peers; teachers may open up on the web for collaborative studying and teaching in the international situation and additionally useful for physically challenged students. It would additionally make the experience that intensive use of such state-of-the-art technological knowledge in educating pedagogical in higher education, in addition, enables the instructors and college students to interact digitally, web-based learning, growing dialogue groups, etc. (Ansari and Khan, 2020).

\section{Conclusions}

The appropriate EdTech tools, which help the curricula, were recommended. The results exhibit that online pedagogy for literature subjects have active approaches and strategies to facilitate teaching and learning such as remodeling a Web-based environment and platform into an intimate social community spanning establishments and individual student. Literature professors should not think that because they are under the branches of the human sciences, they cannot, like other disciplines, not benefit from the facilities and tools of educational technology, particularly in online education, themselves and their students. These educators should try to adapt to the technology of the day and learn the updated methods and strategies to use them in the online classroom environment. With the help of their creativity and experience and collaboration with other colleagues, they can improve 
their teaching abilities and skills in the online space and provide a more enjoyable and productive learning environment. In this article, an example of a useful educational platform for academics is introduced with approaches on how to use it as a generalizable instance that can help to teach literature courses effectively in universities. These strategies and approaches can provide the ground for literature educators with their knowledge, experience, and creativity to be able to use these strategies in a way that is compatible with their learning environment and the level of online classroom students.

Ultimately, it is recommended to study other social media platforms for teaching English literature online and compare the different approaches to use.

\section{References}

[1] Ansari, J.A.N., Khan, N.A. (2020). Exploring the role of social media in collaborative learning the new domain of learning. Smart Learn. Environ. 7, 9 https://doi.org/10.1186/s40561-020-00118-7

[2] Ariadurai, SA, \& Manohanthan, R. (2008). Instructional strategies in teaching engineering at a distance: faculty perspective. International Review of Research in Open and Distance Learning, 9(2), 1-11.

[3] Asgari, S., \& Mehrpouyan, A. (2016). IT Trends and Practices for E-Learning Development in Higher Education. Indian journal of science and technology, 9, 1-9.

[4] Bonk, CJ, \& Cunningham, DJ (1998). Searching for learner-centered, constructivist, and sociocultural components of collaborative educational learning tools. In CJ Bonk, KS King (Eds.), Electronic collaborators: learnercentered technologies for literacy, apprenticeship, and discourse, (pp. 25-50). Mahwah, NJ: Erlbaum.

[5] Bonk, CJ, \& Dennen, VP (2003). Frameworks for research, design, benchmarks, training, and pedagogy in web-based distance education. In MG Moore, WG Anderson (Eds.), Handbook of distance education, (pp. 245-260). Mahwah, NJ: Lawrence Erlbaum Associates.

[6] Davis, KS, \& Snyder, W. (2012). Fostering science education in an online environment: are we there yet? Journal of College Science Teaching, 42(2), 24-31.

[7] Gemmell, I, Sandars, J, Taylor, S, Reed, K (2011). Teaching science and technology via online distance learning: the experience of teaching biostatistics in an online master of public health program. Open Learning: The Journal of Open, Distance, and e-Learning Retrieved from http://www.informaworld.com/smpp/title content=t713440064.

[8] Huan, X, Sheshane, R, Ali, A. (2011). Teaching computer science courses in distance learning. Journal of Instructional Pedagogies, 6(1), 1-14 
[9] Instructional Strategies for Online Courses (2011). University of Illinois, https://www.uis.edu/ion/resources/tutorials/pedagogy/instructionalstrategies-for-online-courses/

[10] Ku, HY, Heng-Yu, K, Akarasriworn, C, Glassmeyer, DM, Mendoza, B, Rice, LA. (2011). Teaching an online graduate mathematics education course for inservice mathematics teachers. Quarterly Review of Distance Education, 12(2), 135-147.

[11] Lancashire, Ian. (2009). Teaching Literature and Language Online, Options for Teaching.

[12] Lawton, D, Vye, N, Bransford, J, Sanders, E, Richey, M, French, D, Stephens, R. (2012). Online learning based on essential concepts and formative assessment. Journal of Engineering Education, 101(2), 244-287.

[13] Majeski, R, \& Stover, M. (2007). Theoretically based pedagogical strategies leading to deep learning in asynchronous online gerontology courses. Educational Gerontology, 33(3), 171-185.

[14] Miller, ST, \& Redman, SL. (2010). Enhancing student performance in an online introductory astronomy course with video demonstrations. Astronomy Education Review, 9(1). https://doi.org/10.3847/AER2009072.

[15] Moore, M. (1991). Distance education theory. The American Journal of Distance Education, 5(3), 1-6.

[16] Myers, MP, \& Schiltz, PM. (2012). Use of Elluminate in the online teaching of statistics in the health sciences. Journal of Research in Innovative Teaching, 5(1), 53-62.

[17] Steinberg, MV. (2010). Teaching introductory statistics and probability online in a paced format: some best practices. Journal of Research in Innovative Teaching, 3(1), 193-202.

[18] Strang, DK. (2012). Skype synchronous interaction effectiveness in a quantitative management science course.Decision Sciences Journal of Innovative Education, 10(1), 3-23. doi:10.1111/j.1540-4609.2011.00333.x.

[19] Summers, JJ, Waigandt, A, Whittaker, TA. (2005). A comparison of student achievement and satisfaction in an online versus a traditional face-to-face statistics class. Innovative Higher Education, 29(3), 233-250.

[20] Thomas, D, Qing, L, Knott, L, Zhongxiao, L. (2008). The structure of student dialogue in web-assisted mathematics courses.Journal of Educational Technology Systems, 36(4), 415-431. doi:10.2190/ET.36.4.e.

[21] Yang, D. Instructional strategies and course design for teaching statistics online: perspectives from online students. IJ STEM Ed 4, 34 (2017). https://doi.org/10.1186/s40594-017-0096-x

[22] York, C, Yang, D, Dark, M. (2007). Transitioning from face-to-face to online instruction: how to increase presence and cognitive/social interaction in an online information security risk assessment class. International Journal of Information and Communication Technology Education, 3(2), 42-52. 
[23] Zhang, J, \& Walls, RT. (2006). Instructors' self-perceived pedagogical principle implementation in the online environment. The Quarterly Review of Distance Education, 7(4), 413-426. 